\title{
The Influences of Implementation of Concept's Learning Model With Scientific Approach to Students Physics Learning Achievement of Junior High School in Banda Aceh
}

\author{
Mustafa $^{1}$, Soewarno ${ }^{1}$, Ida Hayati ${ }^{1}$, Mursalin $^{2}$,Wahyuddin Albra ${ }^{3}$, M Heikal $^{3}$, \\ Apridar Abdurrahman ${ }^{3}$ and M Khaddafi ${ }^{4}$ \\ \{mustafa@unsyiah.ac.id \} \\ ${ }^{1}$ Department of Physics Education, Universitas Syiah Kuala, Banda Aceh, Indonesia \\ ${ }^{2}$ Department of Mathematics Education, Universitas Malikussaleh, Aceh Utara, Indonesia \\ ${ }^{3}$ Department of Management, Universitas Malikussaleh, Aceh Utara, Indonesia \\ ${ }^{4}$ Department of Accounting, Universitas Malikussaleh, Aceh Utara, Indonesia
}

\begin{abstract}
This study aims to examine the effect of theapplication of conceptual learning model with ascientific approach to physics learning achievement of Junior High School students of Banda Aceh City. The design of this research is Quasi-experiment with aquantitative approach, involving 38 junior high school students. This research was conducted one experiment class and one control class at the Junior High School (SMPN 8) Banda Aceh academic year 2017/2018. The instruments used are multiple choice test questions with four options. Data collection techniques, conducted learning process using conceptual learning model with a scientific approach in the experimental class and learning science approach in the classroom control. Results of data processing obtained tcount 5.77 and ttable versus 1.68 at a significant level with degrees of freedom $\mathrm{dk}=36$. Thus thitung>ttabel. Thus it can be concluded that there is theinfluence of conceptual learning model with ascientific approach to student achievement of Junior High School (SMP) Banda Aceh. Thus it can be concluded that the learning achievement of experimental class students taught using conceptual learning model with scientific approach get higher mean value compared to control class students who are not taught using conceptual learning model with ascientific approach.
\end{abstract}

Keywords: Concept Learning Model, Scientific Approach, Learning Outcomes

\section{Introduction}

Education has an important role in the process of development of a nation because education can determine the decline in the implementation of nation-building in all fields. Therefore, the government continues to make efforts to improve the quality of education. One of the efforts in improving the quality of education, especially in schools by improving the teaching and learning process. An educator plays an important role in the learning process and designs a good range of learning. In addition, an educator must be able to help students in 
learning by creating various circumstances that lead to the goal of learning. Teacher's duties and roles include: mastering and developing learning materials, planning and preparing lessons, controlling and evaluating student activities [1].

The determination of the material and the design of learning is very dependent on the subjects taught. In the learning process, there are various subjects taught one of them is a physics lesson. Through the lessons of physics students are expected to gain knowledge and experience in the form of reasoning ability by using various concepts and principles of physics. One of the objectives of the physics subject is to master the knowledge, concepts, and principles of physics, and to have knowledge, skills and scientific attitude [2]. For the purpose of learning, physics needs to be done learning process that can facilitate students in learning.

The learning process in schools that are still teacher-centered makes students have difficulty in learning. The percentage of students' high student learning difficulties can still be known to many students after the teaching and learning process has not reached the minimum completeness level (KKM) that has been established in the school concerned. There are still students who hear and record the subject matter given the teacher. Side recognition at the time of preliminary research prior to this study was carried out, stating that physics lessons are very difficult, too many physics studies formulas and theories. Therefore, students are less motivated to follow the less enjoyable learning process. In addition, newly received knowledge is not related to the knowledge that has been previously owned. A student has difficulty in understanding a certain knowledge, caused in the process of student learning there is no relationship between the concept given to the concept that has been owned. (Trianto, 2009). It is necessary that the model of learning applied by teachers in the classroom can make students understand by linking shared physics concepts learned with previously known concepts.

To overcome the above problems this research provides a solution by applying conceptual learning model with a scientific approach. Application of conceptual learning model with a scientific approach to answering the research question. In addition, students can make learning more effective and student-centered. In this way students can make observations, seek, and can formulate their own concept concepts that have been studied. This conceptual learning model requires students to understand the concepts they have learned. According to Suyono and Hariyanto [10] Learning concept is related to the understanding and use of concepts that have been studied. The learning process of the concept begins with recognizing the name of the concept and its meaning as a knowledge both concrete and abstract concepts, the nature of the concept, the concept function.

The concept is a cluster or a group of facts/information that have to mean [10]. The concept is an abstract pattern that can be used in expressing various factors, symptoms, and problems being studied or a collection of conclusions summarized from a set of data that characterize this in accordance with that disclosed by Sanjaya [20], the concept is the abstraction of similarity or connectedness of a group of objects or properties. A concept has a section called an attribute.

The attributes of each concept have a number of different attributes [11]. Attributes are characteristics possessed by a concept. The combination of these attributes makes the distinction between one concept and another. Further Dahar [4] states the concept is the basis for higher mental processes to formulate principles and generalizations. To solve a problem, a student must know the relevant rules and rules based on the concepts he/she obtains. So understanding the concept means understanding something abstract so that students are motivated to think deeper. The abstract of this concept can be seen from other concepts. 
Learning the concept of physics by using a model of learning the concept of individual syntax. Learning conceptual learning model with scientific approach can facilitate students in understanding the various concepts of physics that teachers teach. Learning concepts concerning the understanding and use of concepts ". Concepts are symbols of thought, derived from the result of making interpretations of facts, principles, procedures or natural phenomena of relationships between facts. Nasution [17] said learning a concept is the ability of students to hold an internal representation of the surrounding world by using language. The learning process is not just memorizing concepts or facts (root learning), but trying to connect the concepts to produce a complete understanding so that the concepts learned will be understood well and not easily forgotten. Learning concepts is learning to discover for yourself the concepts he/she learns. As Dahar [4] says, learning concept is the main result of the learning process in education.

This study was conducted to examine whether there is the influence of the application of conceptual learning model with a scientific approach to learning outcomes in physics lessons. The results of this study are expected to be useful for physics subject teachers in an effort to improve the effectiveness of physics learning outcomes.

\section{Literature Review}

\subsection{Definition of Learning}

The learning is a process marked by a change in self [12]. Changes as a result of the process are indicated in various forms such as changes in knowledge, understanding, attitudes, and behavior, skills, skills, and abilities as well as changes in other aspects that exist in the learning individual.

Learning is an activity in the learning process where students connect the various concepts already in memory with new knowledge [13]. Learning is the process of building knowledge through the transformation of experience. The learning process itself is individual and contextual, meaning that the learning process occurs within the individual in accordance with its development and environment.

Learning activities include three phases. Those phases are exploration phase, concept introduction, concept application [14]. Exploration phase where students learn the concept concepts and natural phenomena around them. The introduction phase of the concept of students performs learning activities to recognize and understand concepts that have something to do with the surrounding events and the concept application phase, where students use the concept to perform various oppression that occurs in each of the other symptoms further. Various concepts that students learn are the knowledge that has its own characteristic of each concept. Many experts who say the concept is a cluster or a group of facts/information that have to mean [15].

The concept is an abstract pattern that can be used in expressing the various factors, symptoms, and problems being studied or a collection of conclusions summarized from a set of data that characterize this in accordance with that disclosed by Sanjaya [20]. The concept of an abstraction that has interrelated attributes that have certain properties underlying higher mental processes in formulating theories, laws, principles, and generalizations [4]. A student to solve a problem needs to know and understand the relevant rules that apply to the concepts it acquires. So understanding the concept means understanding something abstract so that 
students are motivated to think deeper. The abstract of this concept can be seen from other concepts.

Learning concepts is a learning activity to under-stand a knowledge. The concept is a symbol of the results of thought, obtained from the results of the interpretation of facts, principles, procedures or natural phenomena that are interconnected between various facts and phenomena [16][17]. Conceptual learning can be done by students indefinitely, using language, the math of its ability to abstract various events around it. Therefore, teachers need to know and explore the concepts that students have before learning starts. Teachers need as a motivator should help students in linking newly learned concepts with the concept they had.

The learning process not only memorizes concepts or facts but needs to connect newly learned concepts with existing concepts. In this way, student students will have and understand the new concept in depth and will not be easily forgotten. Learning concept is the activity of students by finding their own and gain new knowledge from the learning result [4].

\subsection{Conceptual Learning Model with Scientific Approach}

The model is the design of a series of activities to achieve a particular goal. Models are usually not used to describe something complicated but are used to simplify the process so that it is easier to understand. While learning is the process of interaction of learners with educators and learning resources on a [22][23].

The learning model is a learning activity that must be done by teachers to students to achieve effective and efficient learning objectives. Learning models play a role in facilitating learners to achieve optimal learning outcomes and teachers as facilitators and students as learning objects. Learning model that is used in accordance with the material to be taught [9].

The learning model is a planning or a pattern used as a guide in planning the learning [24] Planning and instructional design is an important step for the purpose of learning to be achieved effectively and efficiently. In planning is the process of preparing the learning guide.

A scientific approach is an approach that applies skilled learning, such as observing, classifying, measuring, predicting, explaining, and concluding. In practice, teachers have a very important role. In addition, this approach makes the learner active, creative, and responsible for the knowledge gained. The steps of the scientific approach are as follows; 1) observe; 2) questioning; 3 ) collecting data, exper-

imenting, exploring; 4) associate; 5) communicate [26].

\subsection{Conceptual Learning Model}

The conceptual learning model is a series of questions given by the teacher in a particular order. A conceptual learning model designed to assist students in developing and strengthening students' understanding of their learning. A conceptual learning model that prioritizes students' conceptual understanding [23]. Therefore teachers need to make students understand concepts actively, creatively, effectively, internally and fun for students so that concepts are easy to understand and survive in the cognitive structure of students.

Concept learning models need to be used in the learning process to build, develop concepts and train critical thinking skills. In a learning that applies the conceptual learning model aims to make students able to think critically and understand the various concepts he/she studies. The conceptual learning model is designed to assist students in achieving learning goals so that students can think critically and make it easier for students to understand the various concepts they are learning [28]. 
The learning steps using conceptual learning model with scientific approach can be described in table 1 below.

Table 1. Steps of Concept Learning Model with Scientific Approach

\begin{tabular}{|c|c|c|}
\hline Phase & Description & Scientific approach \\
\hline $\begin{array}{l}\text { Phase 1: } \\
\text { Introduction }\end{array}$ & $\begin{array}{l}\text { The teacher introduces the lesson and } \\
\text { explains how the activity will be performed }\end{array}$ & \\
\hline $\begin{array}{l}\text { Phase 2: Example } \\
\text { and Formulate } \\
\text { Hypotheses }\end{array}$ & $\begin{array}{l}\text { Students are given one or two examples and } \\
\text { are not examples, students hypothesize the } \\
\text { possibility of a concept they are learning. }\end{array}$ & $\begin{array}{l}\text { Observing, Asking, Collecting } \\
\text { data/ } \\
\text { information }\end{array}$ \\
\hline $\begin{array}{l}\text { Phase 3: Analysis } \\
\text { Cycle }\end{array}$ & $\begin{array}{l}\text { Examples and non-examples are given, } \\
\text { students remove the existing hypotheses and } \\
\text { add new hypotheses based on the new } \\
\text { example (non-example). }\end{array}$ & Reasoning/associating \\
\hline $\begin{array}{l}\text { Phase 4: The } \\
\text { closes and } \\
\text { Applied }\end{array}$ & $\begin{array}{l}\text { A single hypothesis is separated and defined } \\
\text { as well, additional samples are analyzed by } \\
\text { definition }\end{array}$ & Communicate \\
\hline
\end{tabular}

Source: (Paul and Don, 2012),

\subsection{The Learning Outcomes}

The learning outcomes are everything that belongs to students as a result of learning activities that have been done or the final value of a learning process, namely the process of learning from the students do not know to know, the process from before understand to understand, and the process of mutual understanding between teachers with students. [21] says that learning outcomes are patterns of deeds, values, insights, attitudes, appreciations, and skills". As in the 2013 curriculum, achievement of learning outcomes includes three aspects, namely: cognitive aspects, psychomotor aspects, and affective aspects.

As Gagne points out in Suprijono [26]. The learning outcomes are the following: (1) verbal information, ie the capability of expressing knowledge in the form of language, both oral and written. Ability to respond specifically to specific stimuli. It does not require symbol manipulation, problem-solving, or rule implementation. (2) intellectual skills, namely the skills of presenting concepts and symbols. Intellectual skills consist of categorizing skills, analytical abilities-synthetic fact-concepts, and development of scientific principles. (3) cognitive strategy, ie the ability to channel and direct its cognitive activity. These capabilities include the use of concepts and rules in solving problems. (4) motoric skills, ie the ability to perform a series of physical movements in the affairs and coordination so as to manifest the automatism of physical motion. (5) attitude is the ability to accept or reject the object based on the assessment of the object. Attitudes in the ability to internalize and externalize values. Attitude is the ability to make values as standards of behavior.

The same thing is expressed by Thobrani [29] that learning outcomes can be verbal information, intellectual skills, cognitive strategies, motor skills, and attitudes, Dimyati and Mudjiono [6] say, "learning outcomes are a success rate achieved by students after attending a learning activity, where the success rate is marked by the scale of the value of letters, words or symbols". Both the poor results of learning can be seen from the results of measurements in the form of evaluation that can also be used to determine the extent of the level of involvement of students in following the learning process. To state that a teaching and learning process is said to be successful, every teacher has their respective views in line with his philosophy. However, to equate perceptions, we should be guided by the current curriculum that has been 
improved, such that a teaching and learning process of a teaching material is declared successful if ICT (Special Instructional Goals) can be achieved [3].

\section{Methods}

This research uses a quantitative approach to the experimental and survey [25]. Quasimethods of experimental design have been used in this study. This research consists of two class groups, namely experimental class study group and control class learning group (Sugiyono, 2010).

The determination of experimental class and control class is done by random sampling. The experimental class students were given the treatment of the learning modelconcept with a scientific approach whereas control class students are not given treatment, but only taught with traditional learning models. This research variable is conceptual learning model with the scientific approach as free variable and student learning result as the dependent variable. This research was conducted at Public Junior High School (SMPN 8) Banda Aceh.

A total of 165 students of class VII at Public Junior High School (SMPN 8) Banda Acehas a population of this study and have been selected by random sampling as many as 68 students as a Sample consisting of one experimental class and one control class. Determination of research samples that are appropriate according to Sugiyono (2011) which states bring random sampling technique can be considered a homogeneous sample.

This study has been collecting data since July 24, 2017, until August 23, 2017. Data collection through the test as said by Sudjana [24] which states that the test can provide questions to students to get students' answers in the form of oral and written. The test is used to assess and measure student learning outcomes. Test items are given in the form of multiplechoice questions that match the indicators compiled in the Lesson Plans.

The test is in the form of a post-test question that students are expected to use critical thinking skills in understanding concepts and solving problems. The test given to the experimental class group is the same as the test in the control class group. The problem with this test first made a grid problem in accordance with the concept indicators to facilitate and be a clue in writing the question items. The justification of the test items item has been done before the matter is distributed to the respondent.

The data processing that has been obtained from student learning result is analyzed by using t-test. Hypothesis testing is done by tabulating the data in frequency distribution list. Sudjana [24] states that, in order to create a frequency distribution table of the same class length, it is first determined; 1) range, ie the largest data minus the smallest data; 2) the number of interval classes required.This analysis uses the Sturges rule, ie many classes:

$$
1+(3, .3) \log n
$$

(3) the length of the interval class by the formula:

$$
p=\frac{\text { interval }}{\text { many classes }}=\text { interval(number of classes). }
$$


The next stage determines the average of each class by using the formula:

$$
\bar{X}=\frac{\sum f_{i} X_{i}}{\sum f_{i}}
$$

$\bar{X}=$ the average value. $\mathrm{f}_{\mathrm{i}}=$ frequency according to class mark. $\mathrm{X}_{\mathrm{i}}=$ interval class mark.

Homogeneity test was used to find out whether the two sample groups had the same variant or not (Sudjana, 2005). Before determining the standard deviation, we first analyze the variance by using the formula:

$$
S^{2}=\frac{\left(n \sum f i x i^{2}-\left(\sum f i x i\right)^{2}\right.}{n(n-1)}
$$

To determine the standard deviation, then the equation formula:

$$
S^{2}=\frac{\sqrt{\left(n \sum f i x i\right)^{2}-\left(\sum f i x i\right)^{2}}}{n(n-1)}
$$

Hypothesis test used equation formula:

$$
X^{2}=\sum_{i=1}^{K} \frac{\left(O_{i}-E_{i}\right)^{2}}{E_{i}}
$$

Testing the hypothesis by using the $\mathrm{t}$ test formula as follows:

$$
t=\frac{X_{1}-X_{2}}{S \sqrt{\frac{1}{n_{1}}+\frac{1}{n_{2}}}}
$$

with one sample test at a significant level $\alpha=0.05$. [24]

\section{Results and Discussions}

The data collected were pre-test results from experimental class students and from control class students. The results of the pre-test of both groups are as for Table 2 below.

Table 2: Pre-test and Post-test of the experimental class

\begin{tabular}{|c|c|c|c|}
\hline No. & Students ID & $\begin{array}{c}\text { Pre-test of the experimental } \\
\text { class }\end{array}$ & $\begin{array}{c}\text { Post-test of the } \\
\text { experimental class }\end{array}$ \\
\hline 1 & 8746 & 42 & 92 \\
\hline 2 & 8747 & 33 & 83 \\
\hline 3 & 8748 & 43 & 58 \\
\hline 4 & 8749 & 25 & 75 \\
\hline 5 & 8750 & 42 & 92 \\
\hline 6 & 8751 & 25 & 75 \\
\hline 7 & 8746 & 42 & 83 \\
\hline 8 & 8747 & 33 & 75 \\
\hline
\end{tabular}




\begin{tabular}{|c|c|c|c|}
\hline 9 & 8748 & 43 & 83 \\
\hline 10 & 8755 & 33 & 75 \\
\hline 11 & 8756 & 42 & 83 \\
\hline 12 & 8757 & 42 & 92 \\
\hline 13 & 8758 & 33 & 75 \\
\hline 14 & 8759 & 25 & 67 \\
\hline 15 & 8760 & 25 & 83 \\
\hline 16 & 8761 & 43 & 92 \\
\hline 17 & 8763 & 33 & 83 \\
\hline 18 & 8764 & 17 & 65 \\
\hline 19 & 8765 & 25 & 75 \\
\hline 20 & 8766 & 17 & 67 \\
\hline
\end{tabular}

Table 3. Post-test of the experimental class

\begin{tabular}{|c|c|c|c|}
\hline No. & Students ID & Pre-test of the control class & Post-test of the control class \\
\hline 1 & 8706 & 33 & 42 \\
\hline 2 & 8707 & 25 & 58 \\
\hline 3 & 8708 & 33 & 50 \\
\hline 4 & 8709 & 33 & 58 \\
\hline 5 & 8710 & 17 & 58 \\
\hline 6 & 8711 & 25 & 63 \\
\hline 7 & 8712 & 17 & 50 \\
\hline 8 & 8714 & 43 & 65 \\
\hline 9 & 8715 & 33 & 58 \\
\hline 10 & 8716 & 42 & 67 \\
\hline 11 & 8717 & 33 & 58 \\
\hline 12 & 8718 & 42 & 67 \\
\hline 13 & 8719 & 17 & 42 \\
\hline 14 & 8720 & 25 & 58 \\
\hline 15 & 8721 & 17 & 58 \\
\hline 16 & 8722 & 42 & 67 \\
\hline 17 & 8723 & 25 & 50 \\
\hline 18 & 8724 & 42 & 67 \\
\hline 19 & 8725 & 42 & 60 \\
\hline 20 & 8726 & 33 & 56 \\
\hline
\end{tabular}

Based on the above tables 2 and 3, the normality and homogeneity analysis of the four data sets has been performed.

Test the normality of the pretest grade of the experimental class as in Table 3.

Table 3. Distribution of test frequency normality of pretest grade of experiment class students.

\begin{tabular}{|c|c|c|c|c|c|c|}
\hline Value & $\begin{array}{c}\text { Class } \\
\text { Limits } \\
(\mathrm{X})\end{array}$ & Z-Score & $\begin{array}{c}\text { Boundaries } \\
\text { Area }\end{array}$ & Area of Area & $\begin{array}{c}\text { Expected } \\
\text { frequency } \\
\left(\mathrm{E}_{\mathrm{i}}\right) .\end{array}$ & $\begin{array}{c}\text { Frequency of } \\
\text { observation } \\
\left(\mathrm{O}_{\mathrm{i}}\right) .\end{array}$ \\
\hline
\end{tabular}




\begin{tabular}{|c|c|c|c|c|c|c|}
\hline & 7,5 & $-2,17$ & 0,4850 & & & \\
\hline \multirow[t]{2}{*}{$8-14$} & & & & 0,0643 & 1,286 & 2 \\
\hline & 14,5 & $-1,41$ & 0,4207 & & & \\
\hline \multirow[t]{2}{*}{$\begin{array}{c}15- \\
21\end{array}$} & & & & 0,1785 & 3,57 & 3 \\
\hline & 21,5 & $-0,65$ & 0,2422 & & & \\
\hline \multirow[t]{2}{*}{$\begin{array}{c}22- \\
28 \\
\end{array}$} & & & & 0,1984 & 3,968 & 6 \\
\hline & 28,5 & 0,11 & 0,0438 & & & \\
\hline \multirow[t]{2}{*}{$\begin{array}{c}29- \\
35\end{array}$} & & & & 0,264 & 5,28 & 4 \\
\hline & 35,5 & 0,87 & 0,3078 & & & \\
\hline \multirow[t]{2}{*}{$\begin{array}{c}36- \\
42 \\
\end{array}$} & & & & 0,1406 & 2,812 & 5 \\
\hline & 42,5 & 1,63 & 0,4484 & & & \\
\hline
\end{tabular}

Normality test results based on table 3 above shows that obtained $\mathrm{X}_{2}$ count $<\mathrm{X}_{2}$ table is 3.54 $<9.49$. This means that the value of the pre-test of the experimental class is normally distributed.

Test the normality of the control class pre-test values as in Table 4.

Table 4: Distribution of test frequency normality of pretest value of control class.

\begin{tabular}{|c|c|c|c|c|c|c|}
\hline Value & $\begin{array}{c}\text { Class } \\
\text { Limits (X) }\end{array}$ & Z-Score & $\begin{array}{c}\text { Boundaris } \\
\text { Area }\end{array}$ & $\begin{array}{c}\text { Area of } \\
\text { Area }\end{array}$ & $\begin{array}{c}\text { Expected } \\
\text { frequency } \\
\text { (Ei). }\end{array}$ & $\begin{array}{c}\text { Frequency of } \\
\text { observation (Oi). }\end{array}$ \\
\hline & 7,5 & $-2,34$ & 0,4904 & & & 1 \\
\hline $8-14$ & & & & 0,0559 & 1,01 & 4 \\
\hline $15-21$ & 14,5 & $-1,51$ & 0,4345 & & & 4 \\
\hline & 21,5 & $-0,66$ & 0,2454 & & & 5 \\
\hline $22-28$ & & & & 0,174 & 3,132 & \\
\hline & 28,5 & 0,18 & 0,0714 & & & 4 \\
\hline $29-35$ & & & & 0,2747 & 4,945 & \\
\hline & 35,5 & 1,02 & 0,3461 & & & \\
\hline $36-42$ & & & & 0,1232 & 2,218 & \\
\hline & 42,5 & 1,87 & 0,4693 & & & \\
\hline
\end{tabular}

Normality test results based on table 4 above shows that obtained $\mathrm{X}_{2}$ count $<\mathrm{X}_{2}$ table that is $1.77<9.49$. This means the value of the normal distribution control pre-test.

Test the normality of Post-test experimental class as in Table 5.

Table 5: Distribution of test frequency normality of post-test value of experiment class.

\begin{tabular}{|c|c|c|c|c|c|c|}
\hline Value & $\begin{array}{c}\text { Class } \\
\text { Limits } \\
(\mathrm{X})\end{array}$ & Z-Score & $\begin{array}{c}\text { Boundaris } \\
\text { Area }\end{array}$ & $\begin{array}{c}\text { Area of } \\
\text { Area }\end{array}$ & $\begin{array}{c}\text { Expected } \\
\text { frequency } \\
\text { (Ei). }\end{array}$ & $\begin{array}{c}\text { Frequency of } \\
\text { observation } \\
\text { (Oi). }\end{array}$ \\
\hline & 57,5 & $-2,25$ & 0,4878 & & & \\
\hline
\end{tabular}




\begin{tabular}{|c|c|c|c|c|c|c|}
\hline $58-64$ & & & & 0,0572 & 1,144 & 2 \\
\hline & 64,5 & $-1,48$ & 0,4306 & & & \\
\hline $65-71$ & & & & 0,1633 & 3,266 & 3 \\
\hline & 71,5 & $-0,73$ & 0,2673 & & & \\
\hline $72-78$ & & & & 0,2553 & 5,106 & 4 \\
\hline & 78,5 & 0,03 & 0,0120 & & & \\
\hline $79-85$ & & & & 0,2644 & 5,288 & 6 \\
\hline & 85,5 & 0,76 & 0,2764 & & & 5 \\
\hline $86-92$ & & & & 0,163 & 3,26 & \\
\hline & 92,5 & 1,55 & 0,4394 & & & \\
\hline
\end{tabular}

Normality test result based on table 5 above shows that obtained $X_{2}$ count $<X_{2}$ table is 2.00 $<9.49$. This means the value of post-test experiments is normally distributed.

Test the normality of Post-test control classes as in Table 6.

Table 6: The frequency distribution of the normality test of post-test value of the control class.

\begin{tabular}{|c|c|c|c|c|c|c|}
\hline Value & $\begin{array}{c}\text { Class } \\
\text { Limits (X) }\end{array}$ & Z-Score & $\begin{array}{c}\text { Boundaris } \\
\text { Area }\end{array}$ & $\begin{array}{c}\text { Area of } \\
\text { Area }\end{array}$ & $\begin{array}{c}\text { Expected } \\
\text { frequency } \\
\text { (Ei). }\end{array}$ & $\begin{array}{c}\text { Frequency of } \\
\text { observation } \\
\text { (Oi). }\end{array}$ \\
\hline & 49,5 & $-1,60$ & 0,4452 & & & 5 \\
\hline $50-56$ & & & & 0,1841 & 3,313 & \\
\hline & 56,5 & $-0,71$ & 0,2611 & & & 3,344 \\
\hline $57-63$ & & & & 0,1858 & & \\
\hline & 63,5 & 0,19 & 0,0753 & & & \\
\hline $64-70$ & & & & 0,2868 & & \\
\hline & 0,5 & 1,09 & 0,3621 & & & \\
\hline $71-77$ & & & & 0,1146 & 2,063 & 1 \\
\hline & 7,5 & 1,99 & 0,4767 & & & \\
\hline $78-84$ & & & & 0,0213 & 0,383 & \\
\hline & 84,5 & 2,88 & 0,4980 & & & \\
\hline
\end{tabular}

Normality test result based on table 6 above shows that obtained $\mathrm{X}_{2}$ count $<\mathrm{X}_{2}$ table is 5.77 $<9.49$. This means the value of post-test control classes is normally distributed.

Homogeneity test of the variance of post-test value has been done to see homogeneity obtained result with price $\mathrm{F}$ arithmetic is 1.38 and $\mathrm{F}$ table is 2.29 , in other words, it can be said that $\mathrm{F}$ arithmetic $<\mathrm{F}$ table. This means both homogeneous variances.

Based on the hypothesis test, the results obtained that students who are taught with conceptual learning model with scientific approach have different learning outcomes with conventional learning model. It can be seen from the mean value of post-test of students learning result which is taught with conceptual learning model with scientific approach is 78.2 , while the mean value of the post-test result of student learning taught with traditional learning model is 62.0 .

Hypothesis testing on the significant level and degrees of freedom $(\mathrm{dk})=(\mathrm{n} 1+\mathrm{n} 2-2)$ ie $\mathrm{dk}=(20+18-2)=36$, obtained $\mathrm{t}$ table 1.68 while $\mathrm{t}$ count 5.77 . Thus $\mathrm{t}$ count $>\mathrm{t}$ table with the test criteria is: reject Ho who said there is no effect of conceptual learning model with a scientific approach to student learning outcomes in experimental class. Thank Ha who states there is influence of conceptual learning model with scientific approach to student learning outcomes in experimental class. 
Referring to table 1 above, it can be seen that the grades of students class post-test taught by using conceptual learning models with science approach scientific higher than the value of students taught by conventional methods. Therefore, conceptual learning model with science approach scientific an alternative learning model that is suitable to be used in physics learning. Besides, it can also be seen the comparison of the values of the two learning models as shown in Figure 1 below.

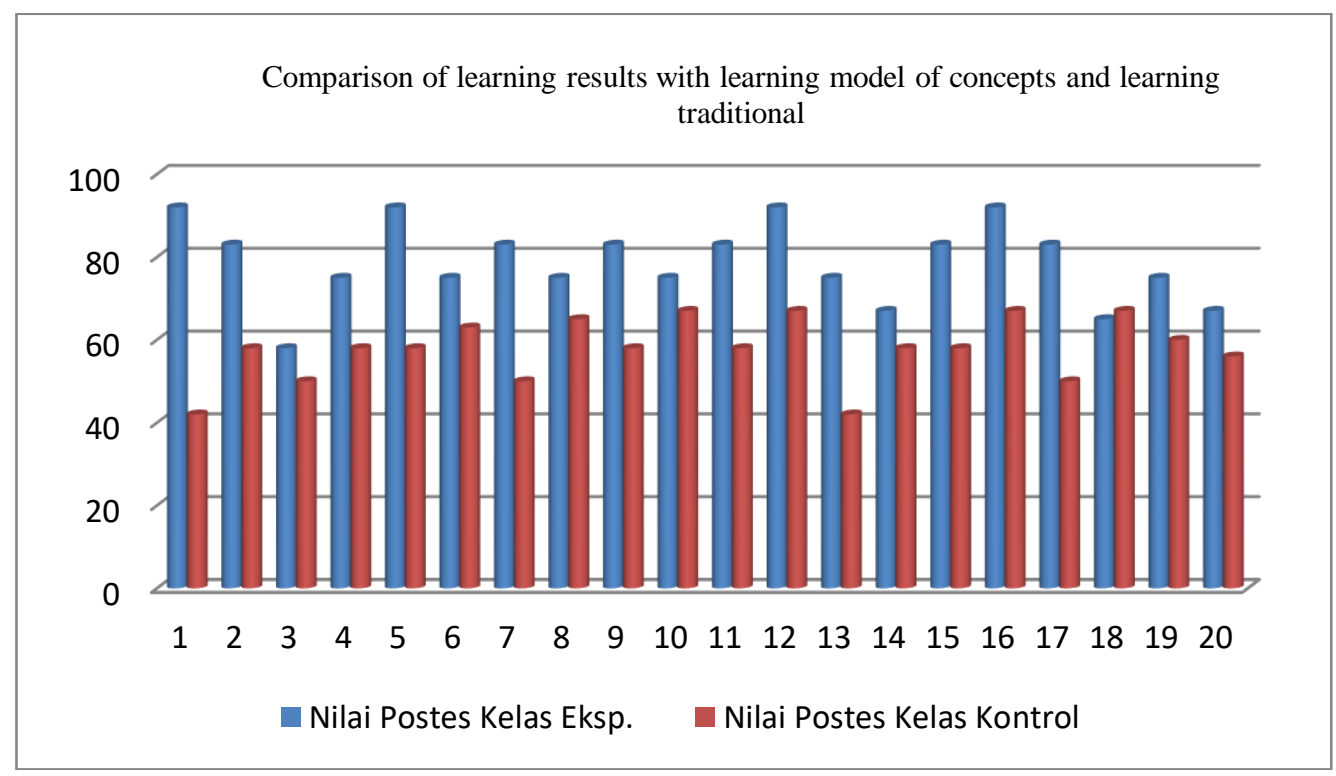

Figure 1. Learning results with learning model of concepts and learning traditional

Referring to figure 1, from two experimental class and experimental class, it is known that experimental class using conceptual learning model with scientific approach resulted in higher student learning outcomes. Improvement of learning result of experiment class student showed that the influence of using concept learning model with scientific approach.

\section{Conclusions}

Based on the results of data processing in this study can be described as follows.

The learning result of the experimental class students taught using conceptual learning model with scientific approach get higher mean value compared to control class which is not taught using conceptual learning model with a scientific approach. The results of Arya (2013) that the activities and learning outcomes of students in the learning process using conceptual learning model has increased. The improvement of learning outcomes obtained by students cannot be separated from the model of learning used by teachers.

Teaching and learning process will be successful if a teacher has to use the appropriate learning model in order to convey the various concepts he taught. In addition to that, teachers also need to use strategies and learning models in accordance with the characteristics of students and concepts of physics are taught. The learning model used by the teacher must be in 
line with the learning objectives that have been determined. The use of appropriate learning models can motivate students and be active in learning.

Conceptual learning model with scientific approach is a model of learning that can motivate students to participate actively in learning. As the results of the research report, Rifda [18] states the conceptual learning model as a model of learning that can improve students' activity in learning. Furthermore, he said that concept learning is a structured inductive learning model consisting of several phases of the individual learning process.

The learning phase of the conceptual learning model as proposed by Dimyati and Mudjiono [4] that conception learning involves three phases. Those phases are exploration phase, concept introduction, concept application. Each of these phases has an explanation and appeals to students active in the learning process. The learning process with conceptual learning model such as this exploratory phase students learns various concepts of physics and its symptoms. In the introduction phase of the concept, students are required to think critically and actively conduct experiments to recognize the concepts he/she studies. Every concept students learn to understand and to relate to events in everyday life.

The learning process with conceptual learning model with teacher's scientific approach only acts as a motivator in every lesson of learning. Teachers as a motivator provide various questions to students that can make students look more active in learning activities. According to Hosnan (2014), a scientific approach is an approach that implements learning that involves students more actively, skillfully, observing, classifying, measuring, predicting, explaining, and concluding, and communicating. In addition, this approach makes the learner active, creative, and responsible for the knowledge gained.

The steps of the learning model with a scientific approach that needs to be developed by teachers, among others; 1) to observe, so that students can relate the various concepts that have been learned with the context of real situations in everyday life, 2) questioning, this activity is one of the processes of building student knowledge in the form of facts, concepts, principles, laws, procedures, and theories and the goal is that students have high-level thinking skills are critical, logical, and systematic; 3) collecting data/ experiment/exploration. This activity needs to be done in the process of learning concept model with a scientific approach to improve students'curiosity in strengthening the understanding of facts, concepts, laws, theory, and procedures in a knowledge. Therefore, the conceptual learning model of a model that can be used by our in the learning process to make students more active.

Concept learning model is a learning model that can streamline the learning process. To engage students more actively in teacher learning, it is necessary to apply conceptual learning models with a scientific approach. The conceptual learning model with the scientific approach makes learning more effective. With the application of conceptual learning, the model can streamline student learning activities such as; conduct observation, record, identify, express opinions, conclude, and communicate various concepts that have been studied.

\section{References}

[1] Ahmar, A.S., Guritno, S. and Abdurakhman. (2013),Pendeteksian Dan Pengoreksian Data Yang Mengandung Additive Outlier (AO) Pada Model ARIMA( $p, d, q)$, Gadjah Mada University.

[2] Arya dan Ganes. (2013). Peningkatan Penguasaan Konsep Dengan Model Pembelajaran Konsep Dalam Pembelajaran IPS Disekolah Dasar. JPGSD, Vol. 1 No.2, pp 117-121.

[3] Bahri, Syaiful Djamara, dkk. (2006), Strategi Belajar Mengajar, Rineka Cipta, Jakarta.

[4] Dahar, Ratna Wilis. (2011), Teori-teori-Belajar dan Pembelajaran, Erlangga, Jakarta. 
[5] Depdiknas. (2003), Standar Kompetensi Mata Pelajaran Fisika, Balitbang Depdiknas, Jakarta.

[6] Dimyati dan Mudjiono. (2009). Belajar dan Pembelajaran, Rineka Cipta, Jakarta.

[7] Don dan Paul. (2012), Strategi dan Model Pembelajaran, PT Indeks, Jakarta Bara.

[8] Emzir. (2013), Metodologi Penelitian: Kuantitatif dan Kualitatif, Rajawali. Hajar, Jakarta.

[9] Fonna, M., \& Mursalin, M. (2018). Role of Self-Efficacy Toward Students' Achievement in Mathematical Multiple Representation Ability (MMRA). Jurnal Ilmiah Peuradeun, 6(1), 31-40.

[10] Hariyanto dan Suyono. (2011), Belajar dan Pembelajaran. PT Remaja, Rosdakarya .

[11] Hosnan. (2014), Pendekatan Santifik dan Kontekstual dalam Pembelajaran Abad 21. Ghalia Indonesia, Bogor.

[12] Ibnu. (1996), Dasar-Dasar Metodologi Penelitian Kuantitatif dalam Pendidikan. PT. Raja Grafindo, Jakarta.

[13] Komalasari, Kokom. (2010), Pembelajaran Konstektual:Konsep dan Aplikasi. PT Refika Aditama.

[14] Matthew dan Hergenhahn. (2010), Theories Of Learning. Kencana.

[15] Moore, R., Lopes, J., (1999). Paper templates. In TEMPLATE'06, 1st International Conference on Template Production. SCITEPRESS.

[16] M. Fonna and M. Mursalin, "Role of Self-Efficacy Toward Students' Achievement in Mathematical Multiple Representation Ability (MMRA)," J. Ilm. Peuradeun; Vol 6 No 1 DOI: 10.26811/peuradeun.v6i1.174, Jan. 2018.

[16] Mudjiono dan Dimyati. (2013). Belajar dan Pembelajaran. Rineka Cipta, Jakarta.

[17] Nasution. (2009), Berbagai Pendekatan dalam Proses Belajar Mengajar. PT Bumi Aksara, Jakarta.

[17] Rahyubi, Heri. (2012), Teori-Teori Belajar dan Aplikasi Pembelajaran Motorik. Nusa Media, Bandung.

[18] Riyanto, Yatim. (2010), Paradigma Baru Pembelajaran Sebagai Referensi Bagi Guru/Pendidik dalam Implementasi Pembelajaran yang Efektif dan Berkualitas. Kencana Prenada Media Group, Jakarta.

[19] Rusman. (2013), Model-Model Pembelajaran: Mengembangkan Profesionalisme Guru Rusman. Rajawali Pers, Jakarta.

[20] Sanjaya,Wina. (2008), Perencanaan dan Desain Sistem Pembelajaran. Kencana PrenadaMedia Group, Jakarta.

[21] Smith, J., (1998). The book, The publishing company. London, $2^{\text {nd }}$ edition.

[22] Subagyo. (2004), Metode Penelitian dalam Teori dan Praktek. PT Rineka Cipta. Jakarta.

[23] Sudijono, Anas. (2005), Pengantar Statistik Pendidikan. Raja Grafindo Persada, Jakarta.

[24] Sudjana, Nana. (2009), Penilaian Hasil Proses Belajar Mengajar. PT Remaja Rosdakarya, Bandung.

[25] Sugiyono. (2010), Metode Penelitian Pendidikan (Pendekatan Kuantitatif, Kualitatif, dan R\&D). Alfabeta, Bandung.

[26] Suprijono, A. (2012), Cooperative Learning Teori dan Aplikasi Paikem. Pustaka Belajar, Yogyakarta.

[27] Suprijono, A. (2012), Cooperative Learning Teori dan Aplikasi Paikem. Pustaka Belajar, Yogyakarta.

[28] Suryosubroto. (2002), Proses Belajar Mengajar di Sekolah. PT Rineka Cipta, Jakarta. Sekolah. PT Rineka Cipta, Jakarta.

[29] Thobroni, Arif. (2013), Belajar dan Pembelajaran. Ar-Ruzz Media, Yogyakarta.

[30] Trianto. (2009, Mendesain Model Pembelajaran Inovatif-Progresif: Konsep, Landasan, dan Implementasinya pada Kurikulum Tingkat Satuan Pendidikan (KTSP). Jakarta: Kencana Prenada Media Group 